\title{
Fim de Ano Com Otimismo
}

Mais um ano que termina. Foi um período que nos trouxe incertezas, dificuldades, ansiedade com um mundo dificil de entender. Mas como nossa especialidade lida com a vida desde o seu início, ela nos faz pensar com otimismo e positividade.

Nossa Federação cresceu mais ainda com demonstrações claras de maturidade. Foi ano de eleição de diretoria, de congresso brasileiro, de avanços técnicos marcantes, e tanto sócio como diretoria souberam, em parceria notória, impor a especialidade no cenário nacional e internacional.

Que o ano 2002 seja no mínimo igual sob este ponto de vista, mas que este nosso lidar com a vida, possa ser praticado com mais otimismo e segurança, reflexo de um mundo mais harmônico e feliz.

A Diretoria 